\title{
Academic Productivity and Political Culture: The Challenges of Higher Education Nowadays
}

\author{
Norma Ávila Báez \\ Universidad Autónoma de Zacatecas \\ Ernesto Menchaca Arredondo \\ Universidad Autónoma de Zacatecas
}

As a result of the new neoliberal education policies, the change in higher education institutions places them on a more competitive and adaptable level, promoting institutional processes of evaluation, planning, accountability and greater intensification of academic work. The articulating axes of political culture are linked to the existence of a subsystem of university government, subject to a process of particular socialization of the exercise of authority that allows their uniqueness within educational institutions, where public policy incentives have a strong capacity to influence the main educational activities and practices of teachers. The existing relationship between academic activity and productivity and its correlation with political culture is analyzed, contemplating subjective aspects and objectives such as beliefs, conceptions, feelings and political values, as well as attitudes, use of language, capacities, behaviors and political practices. Thus, the policy implemented by the education system promotes greater competition among institutions and academics, reshaping the political culture of academics.

Keywords: Academic Productivity, Political Culture, Higher Education

\section{INTRODUCTION}

In Mexico, the importance and key role of public education policies in the construction of the political culture of university academics cannot remain absent from mindset of academic activities. It represents the main work carried out by academics in the substantive activities of teaching, research and extension. In other words, their daily work. Where they see their commitment and how they incorporate, assimilate and reproduce established policies.

This document analyzes empirical data through the main elements that constitute the university political culture, which contemplates subjective traits such as beliefs, conceptions, feelings and political values. It also includes more objective aspects, such as attitudes, language, abilities, behaviors and political practices. Variables related to the level of studies of academics, dedication time, exclusivity to university work, recognitions received, academic productivity, use of educational technologies, leadership and integration to academic groups were taken into consideration. We present the main results of academics' research at the Autonomous University of Zacatecas. As such, the decisions made by 
educational institutions regarding the access, permanence and training of their academic staff are essential for the development of the universities.

\section{Higher Education Institutions Within the Neoliberal Public Policy Context}

The advancement of global capitalism harmed the fledgling university transformation processes. These processes include a homogeneous speech, focused on an adequate pedagogical performance for global development, insights on knowledge transformation and a new role for the university as a workplace, considering that its organizational value is based on the mandates of power across multiple sectors, a world that moves according to the discourse promoted by the neoliberalism based on domination and exclusion (Pérez-Jiménez, 2003). This domination process is linked to the hegemonic creation of beliefs, feelings, attitudes, values and traditions promoted or suppressed through power to produce self-exclusion processes of subjects so that we find ourselves included in the processes, but at the same time excluded if the established parameters are not fulfilled, as part of the political system.

González Casanova (2001) claims that globalizing neoliberalism not only seeks to privatize educational services and materials, it also seeks to quantitatively and qualitatively determine knowledge and know-how needs and objectives in the field of education (2001, p. 25). It further points out that it seeks to adapt plans and programs to the needs of enterprises, with the main objective of facilitating and accelerating the accumulation of wealth and maximizing profits. Such nonsense brought forth the valorization of education as a commodity. As Hugo Aboites said, "In short, a new university order is proposed, centralized and vertical, strongly coordinated with governmental dependencies" (1992, p. 17).

Ibarra Colado (2001) states that the Higher Education Institutions (HEIs) have gone from selfrecognition to a process of institutional change. Terms such as competences, quality, accountability, relevance, mobility, excellence, evaluation, internationalization, academic bodies, academic networks, consortiums, etc. have emerged. These elements are seen as a voluntary cession of HEIs, for their survival and development, due to the onslaught of educational policies imposed by different international organizations and the lack of protection of the State.

Accountability and the establishment of diverse actions to evaluate, validate and improve the quality of educational processes and results are the main transformations. While this type of federal government control over universities has always existed, it has switched from planning processes to quality processes, followed by evaluation, relevance, and now accountability.

Acosta Silva (2010) points out that state intervention relates to how allocated federal resources shape or influence the behavior of university academics. New standards require full-time, betterqualified academics. Within universities and academic programs, processes are adapted to new situations and there is a new institutional readjustment which is manifested in the academic field and the behavior of their communities. Acosta Silva believes that public policies "promote institutional change and provide specific groups of political decisions and actions along with power relations and new ways of government, factors that are influenced by external and internal conditions" (p. 21).

Martínez Espinoza (2006) emphasizes the problem of HEIs by explaining the international and national guidelines that influence the country's education policy. The external guidelines are generated by the Free Trade Agreement (FTA), the Economic Commission for Latin America (ECLAC), the Organization for Economic Cooperation and Development (OECD), and World Bank (WB). These organizations promote the opening of education and universities to international markets.

According to Rubio Oca (2006), public policies with the greatest impetus were: regulation of the educational system and the governance structure of institutions; evaluation and accreditation of universities, programs, teachers and students; internationalization of higher education; and participatory strategic planning. Subsequently, the policy of transparency and accountability introduced in 2003, spread through all policies. For Lora Cam \& Recendez Guerrero (2009), evaluation programs were scattered across a broad spectrum starting with external evaluation, which is carried out by international specialists; then there is self-evaluation where institutions undergo their own evaluation exercise to obtain extraordinary resources; inter-institutional evaluation was diversified throughout diverse programs such as the National System of Researchers (SNI) in 1984, a groundbreaking program in individual evaluation; The National Program for the Improvement of Academic Personnel (SUPERA) for the years 1993-1996,

74 Journal of Applied Business and Economics Vol. 21(7) 2019 
prelude to the Teacher Enhancement Program (PROMEP) in 1996, today identified as the Desirable Profile of the Teacher Performance Enhancement Program (ESDEPED) since 1990, having different names and versions in universities which worked as the mechanism that allows the State to lead and control the activities of teachers while transforming the political culture. Inasmuch as the struggle, search and advancement in freedom of knowledge and research for social welfare has been an ideal gradually abandoned and replaced by the search for individual welfare, certainly with the insertion of new beliefs, attitudes and behaviors.

Strategic participatory planning is another state-driven policy to provoke change. Consolidated in the PIFIs, it represents a process of planning, evaluation and accountability that the universities undertake each year to strengthen and secure the current university political culture in which quality, competence, pertinence, effectiveness, efficiency and more "values" now govern the daily behavior and practice of academics at the expense of autonomy, conceptions, emotions, university regulations, sympathy and scholarly participation.

Implementing these programs would create challenges for higher education development in Mexico. Firstly, to offer educational programs with quality and suitability accessible to diverse social groups; followed by the implementation of a new model of allocation of extraordinary subsidies that recognizes and stimulates the pursuit of academic excellence and lastly, to agree on a state policy in terms of financing, in order to promote the development of the educational sector in the long term (Mungaray, Ocegueda, \& Ocegueda, 2006, p. 149).

These changes, which are managed from outside the institutions, alter the academic activities. While external modification of "daily" events achieves a change, internal dynamics have repercussions externally. During this dialectical process, what is important to explain is precisely how the different university participants assimilate these changes and how they project them to society, in order to create and modify a certain institutional image and create a new university political culture.

\section{Articulators of the Political Culture of University Academics}

University academics are seen as agents that represent their own political culture that is formed and integrated from common values such as their form of government, academic activity and autonomy, where practices are exercised in the context of the institutional subsystem that conform. Thus, over the years, trends are established that identify them as their political values and practices, specific attitudes towards authority and the assimilation of institutional norms and rules. Contributions such as those of Almond and Verba, Trejo Sánchez, Piña Osorio, Cuna Pérez, among others, provide us with elements to establish that political culture is integrated by values, beliefs, conceptions, emotions, capacities, tendencies, attitudes, behaviors and psychological orientations. The main nucleus of these dimensions is found in cultural elements, such as participation that conjugates with psychosocial ones, as well as attitudes that are assumed in front of authority, which can be independent of each other and coexist in the same or different levels, with no hierarchy among them. The abovementioned is the result of one or several elements or their projection as a whole on what they represent and produce on the political conduct and behavior of individuals.

Considering these elements as a starting point, it could be argued that political culture can be reproduced in different fields or social groups, particularly in the university field. There is a political practice among directors, scholars, administrators, students or graduates, namely those who engage daily in the University, within a system of government that reproduces attitudes and values that are taken on in practices and behaviors against authority. Each subgroup can therefore create a certain trend regarding its political culture.

It is important to remember that there is an internal political system within the universities as well as in the country, which maintains a structure of authority represented by university government officials. A further aspect to be considered is the existence of a specific society sector composed of the so-called university community and it is proposed that the State is the main issuer of public policies implemented in higher education, via its different levels of government and institutions. Scholars within this space are subject to a particular socialization process. Even their own authority, which gives them wisdom and 
knowledge, is subject to a process of questioning. These elements represent the uniqueness of the scholar's analysis.

According to Pallán Figueroa (2014) "the State, 'the specifically political component of power in a territorially delimited society' is the generating source of any public organization and, as such, universities are included" (p. 118). The author recognizes that public universities are organizational structures that form part of the Mexican State and, therefore, are subject to rules, regulations, and certain authority, although they have greater independence than other public organizations.

Theoreticians such as Krotz, Gutiérrez, Varela, Sánchez, Abelés, agree that power is one of the elements that shape political culture. From this viewpoint, there is power present in universities - not as the main study topic in this analysis - but it cannot be overlooked, for it is the relationship that makes it possible for the State to establish new values and rules through public policies. It also establishes diverse forms of authority and although these can go against the political culture established in universities and connect with the symbolic power of the State, its directors find themselves faced with a power that defines the political orientation of scholars and public policies specifically, influencing the transformation of the political culture of scholars within the context of the normative pressure existing within the university itself.

Through an analysis of political culture in universities, spaces can be seen where a political subculture can be analyzed. Linton (1945/1978) mentions that in society there are political subcultures, defined as a political culture that arises from the dominant culture in crucial aspects.

Galaz Fontes (2014) argues that existing political culture in universities implies a relationship of subordination to the Subsecretariat of Higher Education through funding policies and a close relationship with state governments, as well as the existence of one or more interest groups within institutions under the protection of academic projects that systematically compete for places and positions for the implementation of their own political-academic agendas. Furthermore, an academic body concerned about itself, its activities and working conditions to meet the requirements of performance incentive programs, with little interest in scholarly activities and a relatively permissive institutional government, yet authoritarian at the same time. To keep order and demonstrate the authority space, thus generating an environment not conducive to university debate.

At the university, political culture manifests itself in several ways, but there are some activities and practices of scholars that allow them to quickly attach themselves to the neoliberal political discourse proposed by the State. As an example, universities have individuals with high levels of knowledge. This means that within the population as a whole there is a minority who had the opportunity to access higher education due to economic issues or intellectual aptitudes. Second, at work, to be inserted in the academic work environment and third, to be part of the organizational teams from where public policies are formally designed.

The concept of political culture is a tool that allows deciphering the extensive network of meanings in which a wide range of new subjects and social movements interact, in such a way that it can be said that there is a political culture of a specific group or sector of university academics, which can explain the main changes and behaviors linked to scientific and technological development and to the process of socialization of the values, rules and institutions that are transmitted within the social development of a country.

The previous features allow to elaborate a concept that defines the university political culture in the following way: such as the group of elements intertwined, tendential and internalized within a subjective dimension (beliefs, conceptions, feelings, values, and knowledge) and an objective dimension (attitudes, language, capacities, behaviors and political practices), that the university academic assumes and carries out because they are imposed from the power structures (university political system).

Subjective and objective dimensions which, upon developing in a symbolic cultural universe, are in constant movement, transforming and developing the life of university scholars, acting as an interconnected gear, where attitudes, language, capacities, behaviors and political practices are deployed, which in turn shape beliefs, conceptions, emotions, knowledge and political values. 
Most definitions of political culture focus on subjective elements. That is why studies of political culture try to focus on people's appreciation of political aspects, but this is not only internalized, but is also a tool that defines the criteria for adaptation to public policies among scholars. By understanding not only values, beliefs and attitudes but also practices, capacities and attitudes university students share modes of existence through which they build their political culture, political institutional relations and, of course, academic relations.

According to Michael J. Sodaro (2004/2006), it is possible to analyze the dimensions that span the concept of political culture, dividing it into patterns of attitudes based on three categories. Attitudes towards authority, society and politics, especially towards the State.

Attitudes in the first category can range from submission, respect, to rebellion. Attitudes towards society can be one of consensus or conflict; at one extreme are very cooperative people and at the other, very conflictive attitudes towards other individuals. These attitudes can also range from collectivism to individualism. Finally, attitudes towards the state can be represented, from the perspective of the individual, as a permissive state or an interventionist state.

These patterns of attitudes, which individuals show to power or the state, allow us to deduce that there may be a space for analyzing the existence of a political subculture. This classification is then taken up again for the interests of this research, exclusively referred to the university environment.

This way, it is possible to analyze the attitudes that university academics possess towards authority, represented by university authority bodies; the attitudes towards society which in this case would be with respect to the university community itself; and, finally, in the attitudes towards the State, surrounded by the incorporation of public policies which, in the educational environment, are implemented in the Autonomous University of Zacatecas, with political culture being understood as a dynamic device.

The most important elements that contribute to the construction of a university political culture are its relative autonomy from the State, the exercise of a representative government and the nature of academic activity. Firstly, autonomy makes it possible to define the institutional organization and the definition of norms, rules and forms of work supervision. The university government establishes a relationship of subordination of the different actors regarding the authority that translates into a dispute for institutional resources and the very nature of academic work oriented to the formation of human resources, research, generation of knowledge and dissemination of culture, defining the predominance of certain social relations among academics. These three major aspects allow the existence of a university political culture.

\section{University Activities}

The role of public education policies determines the development of the political culture of university scholars, as does academic activity, since this represents the main work carried out by scholars as part of the substantive functions of teaching, research and extension, that is, their daily work, in which they see reflected not only their intense dedication, but also the way in which they incorporate, assimilate and reproduce public policies.

The three substantive functions of the university are related: teaching cannot be contemplated without research and both cannot be contemplated without the extension or linkage of its processes with the different sectors of society. Teaching implies the transmission of knowledge by academics. And it constitutes an essential part related to the processes of learning and socialization of ideas, values and practices.

The decisions assumed by educational institutions regarding the access, permanence and education of their academic staff are essential for the development of universities. Currently, some of the main characteristics that academics must meet are (Sanz Blas, Ruiz Mafé, \& Pérez Pérez, 2014): being a specialist in their area of knowledge, professionally trained in the tasks to be performed; teaching, research or management, being enthusiastic and excited about their work and having certain personality traits appropriate to the teaching task, patience, tolerance, empathy, openness, flexibility, availability, creativity, interest in others, etc., maintain certain basic personal skills such as communication, stress management, frustration tolerance, and good interpersonal relationships; must possess job-specific 
teaching skills such as organization and planning, independent and critical thinking. Furthermore, they must maintain a critical and reflective attitude about their own teaching duties and be prepared for changes in their professional performance.

University teaching as a professional activity has experienced many transformations that, like any social practice, unfolds under the society's conditions of development. Teaching has diversified and become more complex in the context of Public Universities. By understanding the academic generically as the professor who dedicates the majority of his daily activities to the university (Porter Galetar, 1999/2000), today they face new institutional commitments, redesigned under the premises of the public policies of incorporation of the evaluation processes to the academic task with different international standards.

A first change has undoubtedly been made from the very concept of profession, centred on the possession of specialised knowledge evidenced by certain formal studies, the public exercise of which is done through the receipt of remuneration (Garduño Madrigal, 1997, Octubre). A knowledge that is modified according to the technical-social requirements of the modern professional system. Teaching is done as a practice, but at the same time, as an intellectual process, and this process articulates in different ways certain practices with the theory in the professional field that constitutes it.

To conceptualize this task in universities, Gil Antón (1994) proposes grouping it into five categories, according to its genesis, profiles and scope of the academic profession: Professionalization through addition of class hours, teaching professional, teaching and research professional, research professional and academic administration professional.

These groupings are mainly defined by the time dedicated to the tasks and the activity it entails, as well as their scope. In such a way that an indicator of the transformation of the political culture in the UAZ can be observed through the category to which it is assigned in its activities, there is no doubt that another element is its antiquity, in addition to its self-location within the university structure, not only physical, but also symbolic.

On the other hand, there are organizational factors that condition the practices of university students; undoubtedly, these organizational modalities that institutions have assumed have conditioned the margins and limits of academic performance. One of the problems they face is the communication with other agents of the educational process, the use of language, the symbolic aspects that guide their daily tasks and tasks, giving meaning to their work.

The main challenge of teaching in universities may be located in the resignification of the role of academics, the construction of status and their identity in their performance within a new function that establishments assign and promote, the dispute for knowledge has resulted in a re-technification in which the flexibilization of academic work is giving pattern to new transformations of university teaching.

Research within HEIs allows the generation of knowledge and is the main axis of any institution. Nevertheless, some institutions are in the process of organizational construction of research processes, others are in the start-up stage and others are in the process of consolidation. A diversified process is located at this point, with varied rhythms and intensities according to a set of indicators related to tradition, critical mass, accumulated scientific capital and physical resources; another differential that responds to the purposes and functions of each institution; a historical process with singular characters in which obstacles and resistances, advances and achievements intervene; the social process structures at the same time the real conditioning of the community in which it is inscribed; while the academic-political commit values, the reasons the scientific construction of knowledge (Sánchez Puentes, 1998).

As part of the official discourse, it is reiterated that the University produces knowledge, communicates it and disseminates it. It seems that it does the same as the scientist and, in order to be considered of quality, the University needs to be endowed with scientificity. Scientificity operates in this logic as an ideal, which serves as a reference point for organization and regulation (Yurén \& Izquierdo, 2008).

The academic, who produces knowledge and disseminates it in congresses and peer-reviewed journals, fulfills the ideal profile of the university academic under a permanent logic of competition and evaluation, in the context of insufficient resources for research, which motivates researchers to link up 
with the business sector, government, civil associations, foundations or any other instance that offers the possibility of financing their research, in such a way that now the State expects that it will be the university itself that "Manages the diversified financial support for the development of its substantive tasks, that makes available the productive protection and the social sector, its resources, infrastructure, graduates, services and research results, which is to be flexible in terms of functional adaptation to the needs of labor markets, goods and services" (Acosta Reveles \& Figueroa Delgado, 2010, p. 143).

Researchers are committed to an academic production in which the elaboration of book chapters and books is predominant, either as sole author, in a collective or as coordinator, participation in congresses with lectures or master conferences, or the construction of relations with adamic peers, which facilitates the exchange of knowledge. The National System of Researchers (SNI) was one of the fundamental changes in the construction of a new university reality, this impacts or directly influences the way in which academics assume a new academic life, since they come to represent a new form of control and mediation of their quality standards in their daily work, not only for the teacher, but for all university institutional life. Through these programs, the institution receives important economic resources and for academics, the incentives to the teaching career represent a considerable percentage of their income.

\section{METHODS AND RESULTS}

To explain the importance of academic activity and the productivity of academics in the existence of their own political culture in higher education institutions and that these are motivated by the public educational policy implemented in these institutions, a study was carried out in the Academicians of the Autonomous University of Zacatecas, in which the political dimension integrated by four aspects was analyzed: 1. the regulation of the educational system and the structure of government of the university institutions, integrated by the variables: predominant university political system, university authority, the influence of leaderships, normativity and the qualification of administrative performance. The evaluation and accreditation of universities integrates the level of studies of the academics, dedication and exclusivity in the institution, academic recognitions obtained, academic productivity, use of technologies, conformation of academic groups and leadership. 3. Internationalization integrates the following variables: academic networks, international academic formation, command of languages. 4. Strategic planning, integrated by: Valuation of research and teaching, dedication, academic work, level of respect for regulations, level of acceptance of public policies, decision making capacity of academics and institutional image.

Empirical data analysis is done through elements based on the university political culture, which contemplates subjective features where beliefs, conceptions, emotions and political values are examined. And objective traits, these traits analyze the attitudes, language, capabilities, behavior, political practices and those shaped in the political culture of UAZ scholars.

The data were analyzed in a descriptive manner; afterwards, in order to achieve a greater representation of the data, an analysis was carried out by main components in each one of the proposed dimensions, as well as an analysis of contrast with the ANOVA procedure to describe with greater clarity the main characteristics of the political culture of the academics of the Autonomous University of Zacatecas; finally, indexes and indicators were constructed that would allow offering greater clarity on the dimensions and variables in comparison.

The objective was to characterize a distribution of diverse values in a single measure, although the loss of information is compensated by greater clarity, usefulness and practical use in the overall analysis. The objective was to comply with the theoretical requirements for the construction of the indices in the sense of their validity, economy, clarity, reliability, comparability, utility, reproducibility and interpretability to explain the values associated with reality.

Regarding academic aspects, variables related to the level of study of academics, dedication and exclusivity to university work, recognition received, academic productivity, use of educational technologies, leadership and integration to academic bodies were considered. An adjacent public policy is internationalization, which was analyzed on the basis of the variables: academic networks, international 
academic training, and mastery of foreign languages. The former include beliefs, conceptions, emotions, political values. The second, attitudes, language, capacities, behaviours and political practices.

With regard to academic training, the results show that $34.55 \%$ of the scholars surveyed have a doctorate degree; 16.4 are studying for a doctorate; $25.0 \%$ have a master's degree; $3.9 \%$ are currently studying for a master's degree and only $11.2 \%$ have a bachelor's degree; for scholars, commitment, honesty, authenticity, participation and creativity should be the main characteristics for academic leadership.

TABLE 1

FIVE MAIN FEATURES THAT AN ACADEMIC LEADER SHOULD HAVE ACCORDING TO UNIVERSITY SCHOLARS (2015)

\begin{tabular}{|l|l|c|c|c|}
\multicolumn{1}{|c|}{ Feature } & N & Average & $\begin{array}{c}\text { Standard } \\
\text { deviation }\end{array}$ & $\begin{array}{c}\text { Standard } \\
\text { error average }\end{array}$ \\
\hline Committed & 162 & 2.2 & 1.4 & 0 \\
Honest & 157 & 2.6 & 1.4 & 0 \\
Authentic & 75 & 3.2 & 2.6 & 0 \\
Participative & 92 & 3.3 & 2.1 & 0 \\
Creative & 88 & 3.5 & 2.3 & 0 \\
\hline Autocratic & 98 & 3.6 & 2.3 & 0 \\
\hline Willing to Work & 62 & 3.7 & 2.5 & 0 \\
\hline Respectful & 88 & 3.7 & 1.9 & 0 \\
\hline Consistency & 74 & 3.7 & 1.6 & 0 \\
\hline Cognitive Capacity & 47 & 3.8 & 3.3 & 0 \\
\hline Reflective & 50 & 3.8 & 2.2 & 0 \\
\hline Shared responsibilities & 41 & 4.1 & 3.7 & 0 \\
\hline Perseverance & 58 & 4.1 & 2.8 & 0 \\
\hline Sensitivity & 50 & 4.2 & 3.1 & 1 \\
\hline Organized & 47 & 4.3 & 2.4 & 0 \\
\hline Democratic & 45 & 4.4 & 3.7 & \\
\hline Proficient with methods and & 40 & 4.9 & 4.2 & \\
techniques & & & & \\
\hline Source: UAZ Questionnaire on University Political Culture and Scientific Activity. Zacatecas, Mexico \\
\hline 2015.
\end{tabular}

Regarding the level of confidence in the development of academic life, the high index is considered higher than 90, where the academic collectives are located, the average level of confidence, with 80 being considered higher and less than 90 being the collective and unipersonal authorities; the low level of confidence, identified with those under 80 , refers to the academic secretary and then to the administrative secretary. 
TABLE 2

\section{LEVEL OF TRUST THAT UAZ ACADEMICS GIVE TO UNIVERSITY ACTORS, ACCORDING TO PERCENTAGE (2015)}

\begin{tabular}{|c|c|c|c|c|c|c|c|c|}
\hline Option & Total. & High. & Medium & Low. & None. & $\begin{array}{l}\text { No } \\
\text { Answer }\end{array}$ & Total & Ratio \\
\hline Academies & 7.8 & 33.6 & 31.0 & 12.0 & 6.5 & 9.5 & 100 & 101 \\
\hline Academic Groups & 6.9 & 32.3 & 33.2 & 11.0 & 5.6 & 11.2 & 100 & 99 \\
\hline $\begin{array}{l}\text { The Program } \\
\text { Manager }\end{array}$ & 16.4 & 31.0 & 16.8 & 9.0 & 9.9 & 16.8 & 100 & 98 \\
\hline University Council & 8.6 & 22.4 & 36.2 & 17.0 & 6.9 & 8.6 & 100 & 95 \\
\hline The Unit Director & 13.4 & 27.6 & 19.8 & 11.0 & 12.5 & 15.9 & 100 & 93 \\
\hline University Court & 6.0 & 21.6 & 38.4 & 16.0 & 8.6 & 9.9 & 100 & 92 \\
\hline Area Manager & 6.9 & 22.8 & 28.4 & 18.0 & 13.8 & 9.9 & 100 & 89 \\
\hline Area Councils & 6.9 & 22.8 & 28.4 & 18.0 & 13.8 & 9.9 & 100 & 89 \\
\hline $\begin{array}{l}\text { University } \\
\text { Advocacy }\end{array}$ & 3.9 & 20.3 & 35.8 & 19.0 & 9.5 & 11.6 & 100 & 87 \\
\hline Dean & 6.5 & 17.2 & 32.8 & 19.0 & 15.9 & 8.2 & 100 & 86 \\
\hline General Secretary & 7.8 & 11.6 & 29.3 & 25.0 & 17.7 & 9.1 & 100 & 82 \\
\hline $\begin{array}{l}\text { Academic } \\
\text { Secretary }\end{array}$ & 4.7 & 11.6 & 29.7 & 26.0 & 17.7 & 9.9 & 100 & 78 \\
\hline $\begin{array}{l}\text { Administrative } \\
\text { Secretary }\end{array}$ & 4.3 & 12.1 & 28.0 & 28.0 & 17.2 & 10.7 & 100 & 77 \\
\hline \multicolumn{9}{|c|}{$\begin{array}{l}\text { Source: University political culture and scientific activity in UAZ questionnaire. } \\
\text { Zacatecas, Mexico } 2015 .\end{array}$} \\
\hline \multicolumn{9}{|c|}{$\begin{array}{l}\text { Note. The index was constructed giving a weight to each one of the options, } 10 \text { points to the } \\
\text { option of total trust, } 8 \text { points to high, } 6 \text { to medium, } 4 \text { to low trust, } 2 \text { to none and } 1 \text { to those that } \\
\text { did not answer, then each percentage was multiplied by the weighting and in the end the } \\
\text { weights were added and divided by the number of options. }\end{array}$} \\
\hline
\end{tabular}

In an analysis by main components the results reveal that the first component, which we call Productivity through Stimuli and Incentives, shows the correlation between the stimulus program to the teaching career and the preparation of books, research results, with chapters of books, book publishing and attendance at conferences and preparation of lectures, as well as the organization of national or international conferences.

The second component, which is called: Evaluation and Integration to Research, reveals the correlation between project evaluation processes, the development of materials for university teaching and the participation of teachers in the accreditation processes of academic programs, regarding the integration of academics into the National System of Researchers.

The third component, called: Dedication and Academic Participation, shows a negative correlation between the PROMEP profile and participation in a research project.

The fourth component, Consultancy Processes, which consists on the participation of academics in consulting processes. 
TABLE 3

\section{VARIABLES OF THE ACADEMIC ACTIVITY COMPONENTS ARRAY OF ROTATED COMPONENTS ${ }^{a}$}

\begin{tabular}{|l|l|l|l|l|}
\hline \multirow{2}{*}{ Variables } & \multicolumn{3}{c|}{ Component } \\
\cline { 2 - 5 } & \multicolumn{1}{|c|}{1} & \multicolumn{1}{c|}{3} & \multicolumn{1}{c|}{4} \\
\hline Research results books & $\mathbf{0 . 9 9 2}$ & -0.013 & 0.038 & -0.035 \\
\hline Review or reference books & $\mathbf{0 . 9 9 2}$ & -0.013 & 0.038 & -0.035 \\
\hline Book edition & $\mathbf{0 . 9 9 2}$ & -0.013 & 0.038 & -0.035 \\
\hline Chapter of books & $\mathbf{0 . 9 0 9}$ & -0.006 & 0.315 & -0.226 \\
\hline Lectures & $\mathbf{0 . 8 5 7}$ & 0.142 & 0.407 & -0.281 \\
\hline $\begin{array}{l}\text { Currently taking part of the program of stimuli to the teaching } \\
\text { career? }\end{array}$ & $\mathbf{0 . 8 1 8}$ & -0.252 & -0.426 & 0.277 \\
\hline $\begin{array}{l}\text { Organization of scientific congresses at national or } \\
\text { international level }\end{array}$ & $\mathbf{0 . 7 9 6}$ & -0.398 & 0.356 & 0.034 \\
\hline Conferences & $\mathbf{0 . 7 5 7}$ & 0.537 & 0.313 & -0.196 \\
\hline Full research articles & $\mathbf{0 . 6 9 6}$ & 0.132 & 0.685 & -0.129 \\
\hline Short research articles & $\mathbf{0 . 6 4 3}$ & 0.612 & 0.229 & -0.131 \\
\hline Currently taking part of the National System of Researchers & 0.375 & $\mathbf{- 0 . 7 5 5}$ & -0.304 & 0.173 \\
\hline Material for university teaching & 0.132 & $\mathbf{0 . 7 9 1}$ & 0.411 & 0.409 \\
\hline $\begin{array}{l}\text { Coordination of the process of preparing documents for the } \\
\text { accreditation of programs. }\end{array}$ & 0.017 & $\mathbf{0 . 7 3 6}$ & 0.607 & .226 \\
\hline Project Evaluation & -0.059 & $\mathbf{0 . 9 7 8}$ & -0.076 & -0.105 \\
\hline Research projects & -0.085 & 0.214 & 0.099 & $\mathbf{0 . 9 6 5}$ \\
\hline Consulting & -0.139 & -0.207 & -0.01 & $\mathbf{0 . 9 6 7}$ \\
\hline Currently you participate in a research project & -0.179 & -0.208 & $\mathbf{- 0 . 9 0 5}$ & -0.325 \\
\hline Currently own a PROMEP profile & -0.276 & -0.379 & $\mathbf{- 0 . 7 3 3}$ & 0.492 \\
\hline
\end{tabular}

Extraction method: main components analysis.

Rotation method: Varimax with Kaiser normalization.

a. The rotation has converged in 6 iterations.

Attitudes represent a person's way of acting, the response to a social event, through which behaviors can be predicted, so they are related to people's beliefs and affections, attitudes represent a variable that It is present in the study of political culture because it is directly related to the phenomena being analyzed.

For Kimball Young (1967) attitudes are defined as the tendency or predisposition learned, more or less generalized and that of affective tone, to respond in a fairly persistent and characteristic way, usually positively or negatively (for or against), with reference to a situation, idea, value, object or class of material objects, or to a person or group of people (Young, Germani, Flügel, \& Argyle, 1967). In this regard, Giacomo Sani mentions that, in the context of political culture, attitudes such as indifference, cynicism, rigidity, dogmatism or tolerance, adherence to norms such as the law or duty of the citizen are part of the political life of the citizen.

According to Almond and Verba (1963/1970), attitudes are an important aspect that allows us to characterize the type of political culture that prevails in a society, although they state that it is the most difficult aspect to determine because there is no specific parameter to describe them, this must be constructed according to the interests of the investigation, since these are the observable response of the individual to a specific situation.

It is important to highlight the attitudes that academics show in relation to university government, particularly before decisions imposed on daily work or in the implementation of educational public 
policy, attitudes that remain but may change according to personal situation in which the academic is or in consonance to changes in their context, in this regard the levels of attitudes of acceptance, rejection, resignation and indifference were defined.

TABLE 4

ATTITUDE INDEX OF UAZ UNIVERSITY ACADEMICS, 2015

\begin{tabular}{|c|c|c|c|c|}
\hline Indicator & Frequency & Percentage & $\begin{array}{l}\text { Valid } \\
\text { percentage }\end{array}$ & $\begin{array}{l}\text { Accumulated } \\
\text { percentage }\end{array}$ \\
\hline Rejection & 1 & 0.4 & 0.5 & 0.5 \\
\hline Indifference & 19 & 8.2 & 8.8 & 9.3 \\
\hline Resignation & 163 & 70.3 & 75.5 & 84.7 \\
\hline Acceptance & 33 & 14.2 & 15.3 & 100,0 \\
\hline Lost by system & 16 & 6.9 & & \\
\hline Total & 232 & 100,0 & & \\
\hline
\end{tabular}

Note: For the construction of the attitude index there were considered the variables related to: attitudes that are assumed on the decisions and resolutions of the university authorities (in academic work, the Dean and $\mathrm{H}$. University Council), attitudes about the implementation of public educational policy (PROMEP, NSR, Academic bodies, tutorials, stimuli, accreditation, evaluation and competencies), level of agreement on the intervention of the state government (appoint authorities, define teaching in classrooms, define lines of research, hire teachers and finance education).

In general terms, the attitudes that predominate are those of resignation, if we look at these aspects in a distribution by gender, we find that male academics show a greater percentage of an attitude of rejection and indifference to academics, but they also show a higher percentage of resignation.

The attitude of resignation is the one that predominates if it is observed in relation to the level of studies of academics, where those who have a master's and doctorate level have the highest percentages; while those that are not incorporated into the ESDEPED have a higher percentage of resignation, as do those that are not part of the NSR.

The employment relationship of academic staff represents another factor that influences the expression of a certain type of attitudes, we could start from the assumption that, among greater job security, academics would assume an attitude of resignation, which would indicate that this is more inclined to a cognitive process. However, the attitude of resignation in the base and full-time staff has the highest percentages, behavior that manifests in a similar way in work time they dedicate to the university where the ranks of greater resignation are located in the academics who have hired between 40 and 50 hours.

For years of employment seniority, the most resigned are those who have between zero and five years working in the institution with the highest percentage, those with a seniority of six to eleven years, however the age group of academics showing a higher percentage of resignation is that which is in the age range of 36 to 41 years and that of 48 to 53 .

These attitudes show the change in the political culture of the academic, the previous decades objected, discussed and proposed the academic course at least the scope of their particular field, in defense of the freedom of professorship, today a greater alignment with the provisions outside, so they have to adapt to their own work in the interest and benefit of the management of the institution.

For this reason there is less rejection of the public policies that are implemented, so internalized conditions are suitable for the implementation of federal programs, for example, ESDEPED, NSR, and CA. Also the set of rules, regulations and guidelines associated with programs such as tutoring, the ESDEPED regulation, the guidelines associated with accreditation, evaluation and competencies, do not cause major disagreements in academics, on the contrary, they observe it as something necessary and indispensable for their personal and institutional academic development, because behind all of them are the economic resources. 
None the less, the intervention of the federal government with the policies implemented for quality, cause the academic to feel part of a change and not perceive that the government is part of the decisions and changes that occur within the institution, This is evident when academics show greater rejection of government intervention. The same occurs in the subject of teaching content, in the definition of research lines or in the hiring of academics. The only thing that they agree on is the financing that the State must grant to Higher Education.

The above elaborates a complex idea about university autonomy, since the opinion of academics considers that the government manifests an interventionist and controlling attitude, but there is another sector that considers the relationship between the university and the government as respectful, permissive and opening.

The attitude of academics in relation to internal provisions, which are assumed within the institution, is shown by the level of trust that is held by academic authorities and not by the top-level administrative authorities, federal and state, since they accept the decisions, if they are legal or out of respect for the authority.

The language index included the level of identification with words such as quality, excellence, relevance, social commitment, critical thinking, transparency, innovation, competitiveness, creativity, justice, freedom, democracy, autonomy and institutional. Although the concepts are contradictory, an indicator of the degree of involvement and importance of the assimilation of words and concepts within the performance and constitution of the political culture of academics can be appreciated.

It is important to highlight that the mean of the values indicates that the words that academics have most assimilated are, in descending order: competitiveness, institutional, innovation, relevance, democracy and excellence. It is understood that then the role of public and institutional policies have permeated academics mainly in these areas. On the other hand, the last words that have been internalized are, in descending order: transparency, social commitment, justice, freedom and quality. Undoubtedly, these aspects indicate that these concepts have the least consideration on the part of academics. Even in spite of the intense policies on the promotion of quality, it is not an aspect that is internalized, as well as aspects related to a culture of greater freedom and justice or the social commitment that the university can assume before any social problems, no doubt transparency remains a factor that is not part of the institutional culture.

TABLE 5

UAZ ACADEMIC LANGUAGE INDEX, 2015

\begin{tabular}{l|c|c|c|c}
\hline \multicolumn{1}{c|}{ Indicator } & Frequency & Percentage & $\begin{array}{c}\text { Valid } \\
\text { percentage }\end{array}$ & $\begin{array}{c}\text { Accumulated } \\
\text { percentage }\end{array}$ \\
\hline Null & 15 & 6.5 & 6.5 & 6.5 \\
Low & 7 & 3.0 & 3.0 & 9.5 \\
Medium & 16 & 6.9 & 6.9 & 16.4 \\
High & 194 & 83.6 & 83.6 & 100,0 \\
\hline & $\mathbf{2 3 2}$ & $\mathbf{1 0 0 , 0}$ & $\mathbf{1 0 0 , 0}$ & \\
\hline
\end{tabular}

Note: The index was constructed with the variables on the level of identification with the words quality, excellence, relevance, social commitment, critical thinking, transparency, innovation, competitiveness, creativity, justice, freedom, democracy, autonomy and Institutional.

The general index on language generally shows a high level of assimilation, practically $84 \%$ is in this indicator. It without a doubt shows that this aspect is of vital importance for the functioning and internalization in the construction of political attitudes and practices, depending on the degree of internalization and acceptance in the daily activities of university academics.

With regard to gender, the index is similar for men and women in such a way that there are no differences in this regard in the way in which this network of ways of assuming academic activities and tasks is constituted. 
With respect to the level of studies, if there are differences in the assimilation of language between greater academic training, greater assimilation exists in such a way that training is essential in the culturing of certain cultural patterns that must be accepted within the university context.

It can be said that there are no differences in the way of assuming language among academics who are or are not integrated into the teacher improvement program. So that it is independent of this type of programs more linked to the process of strengthening certain practices already established by other regulatory systems.

The language index regarding the integration or not of academics into the ESDEPED shows that in both cases there is a high index, although the null index is higher in academics than if they participate in this program, it can be said in general that there are few differences. The behavior is similar in the case of academics who are part of the NSR, so it can be argued that these programs themselves do not make differences with the level of index of identification with the language, the causes must be found in previous aspects to the application of the programs, that is to say at the time of the definition and acceptance of the educational guidelines and policies.

The language index is high among academics with a basic and pre-retired employment relationship, but among those who are basic there are also those who have a null index. This implies few levels of differences in this index with respect to the type of employment contract. This trend is maintained when doing the analysis with respect to the time spent on contracting (HC, MT and TC) the three types maintain high language indices.

By age groups it is observed that those who are in the group between 36 and 41 have the highest levels of the language index, followed by those between 48 and 53, where there is less integration is between certain sectors of academics between 36 and 47 years old

With respect to the degree of language assimilation according to the years of seniority of academic workers, it is observed on the one hand that there is greater identification of those who are less than 11 years of seniority, this means that there was a change in the constitution of the processes linguistics linked to the operation and exercise of the policy and specific political practices within the fundamental activity developed by the academics and to greater seniority less identification.

With respect to the total hours worked by academics, it is clear that those who have a greater workload assume a greater identification on the language and processes that are institutionalized in the university, so that effectively academics with lower workloads will have less identification with the functioning of the political system and, in general, less concern about participating in decisions about the type and general functioning of the university model.

According to the degree of studies it is observed that political values, knowledge, political practices and language are the components that are shared, it is important to highlight that academics who have a master's level show high rates in all components, only the knowledge and political practices are average, this indicates that this level of study presents a process of greater assimilation, unlike those who take a doctorate, all their indicators are medium and when obtaining the doctorate they raise conceptions, feelings and attitudes. 
TABLE 6

INDEXES BY COMPONENT OF POLITICAL CULTURE ACCORDING TO EFFECT BY THE ACADEMIC LEVEL OF THE PROFESSORS

\begin{tabular}{|c|c|c|c|c|c|c|c|c|}
\hline \multirow{2}{*}{ Level } & \multicolumn{8}{|c|}{ Components1 } \\
\hline & 1 & 2 & 3 & 4 & 5 & 6 & 7 & 8 \\
\hline Bachelor & 0 & + & 0 & 0 & - & + & 0 & 0 \\
\hline Specialty & 0 & 0 & 0 & 0 & 0 & - & 0 & + \\
\hline $\begin{array}{l}\text { Studying for a } \\
\text { Master's degree }\end{array}$ & 0 & 0 & 0 & 0 & 0 & - & 0 & + \\
\hline Master & + & + & + & + & 0 & + & 0 & + \\
\hline Studying for a $\mathrm{PhD}$ & 0 & 0 & 0 & 0 & 0 & 0 & 0 & 0 \\
\hline $\mathrm{PhD}$ & 0 & + & + & 0 & 0 & + & 0 & 0 \\
\hline Postdoctoral & - & - & - & 0 & 0 & 0 & 0 & - \\
\hline \multicolumn{9}{|c|}{$\begin{array}{l}\text { Note } 1 . \text { The number of components corresponds to the index average of: } 1 \text {. Beliefs; } 2 \\
\text { Concepts; } 3 \text {. Emotions; } 4 \text {. Political values; } 5 \text {. Knowledge; } 6 \text {. Attitudes; } 7 \text {. Politica } \\
\text { practices; and } 8 \text {. Language. } \\
\text { Note } 2 \text {. The sign }(+) \text { represents a high index, the sign }(0) \text { a medium index and the }(-) \text { a } \\
\text { low index. }\end{array}$} \\
\hline
\end{tabular}

TABLE 7

ACADEMIC WORK AND WORKING HOURS

\begin{tabular}{|c|c|c|c|c|c|c|c|c|}
\hline \multirow{2}{*}{$\begin{array}{l}\text { Workday (Hours } \\
\text { per week a month) }\end{array}$} & \multicolumn{8}{|c|}{ Components 1} \\
\hline & 1 & 2 & 3 & 4 & 5 & 6 & 7 & 8 \\
\hline $21-29$ & - & - & - & + & 0 & + & - & 0 \\
\hline $20-29$ & + & + & + & + & - & - & + & + \\
\hline $40-49$ & 0 & 0 & + & - & 0 & 0 & 0 & 0 \\
\hline 50 & 0 & 0 & 0 & 0 & + & - & - & - \\
\hline \multicolumn{9}{|c|}{$\begin{array}{l}\text { Note } 1 \text {. The number of components corresponds to the index average of: } 1 \text {. Beliefs; } 2 \text {. } \\
\text { Concepts; } 3 \text {. Emotions; } 4 \text {. Political values; } 5 \text {. Knowledge; } 6 \text {. Attitudes; } 7 \text {. Political } \\
\text { practices; and } 8 \text {. Language. } \\
\text { Note } 2 \text {. The sign }(+) \text { represents a high index, the sign }(0) \text { a medium index and the }(-) \text { a } \\
\text { low index. }\end{array}$} \\
\hline
\end{tabular}

The time that integrates the academic working day is constituted in the space where a process of socialization of the political culture is carried out in which the ideological positions influence the way the idea of the university political system is configured.

For this reason, the academic parameter that had a minimum working day of at least twenty hours per week was taken as an analysis parameter since this period of time ensures an average permanence in their workplace, so that it can be observed between academics who develop a day between 20 and 29 hours have a high index of political values and high attitudes, but elements such as political participation, feelings and beliefs are low, as the academic stays longer in their workplace these indicators increase, but knowledge and attitudes go down in a day of 30 to 39 hours at this time allows you to obtain a greater experience of university dynamics, allows you a greater command of language, a greater political practice, an increase in confidence, in your sense of belonging, you can better evaluate university authorities and know the configuration of the university political system, but has low knowledge of its regulations. 


\section{CONCLUSIONS}

It was possible to demonstrate that neoliberal public policies, in particular policies and programs, of quality evaluation, individual and institutional, and the policy of transparency and accountability go through the transversal axes chosen to corroborate change: autonomy, government and academic activity

The way in which public policies are implemented has influenced the transformation of the political culture of UAZ academics, today we are faced with depoliticized academics who have naturalized public policies, have internalized and assumed them in a non-rational manner. The processes of its implementation have transformed the perception of themselves, which implies political unstructuring not only of their practices but also of their values and beliefs, this change brought a fragmented political culture shaped by beliefs, conceptions, feelings, attitudes, behaviors, political values, knowledge and political practices that are particularly linked to daily academic activity, obviously linked to the transformation processes that the university has, due to the incorporation of educational policies.

As we have previously stated, this educational policy is guided by the global globalization process that has focused its interests on productivity at the service of corporations that make use of science, technology and innovation as part of capitalist development, causing a break between national and transnational interests, in what has also been called "knowledge society", transforming not only the political culture but the way of life of academics and in general the aims of higher education in Mexico.

The identification, linked to the words quality, freedom and justice, is part of the cultural assimilation of the new public policies, under a liberal Ralwsian scheme, on justice and freedom, assumes that everyone can participate in their decision or not participate in all these policies, even knowing that there are unfair participation criteria and limitations on their freedom. The factors that give the most status are the greater academic training, attending work meetings and the least valued is to travel constantly and have a higher income.

\section{REFERENCES}

Aboites, V. H. (1992). Recuperación de la universidad pública. Ciudades. Análisis de la coyuntura, teoría e historia urbana, 16, 16-19.

Acosta Reveles, I. L., \& Figueroa Delgado, S. A. (2010). Hacer ciencia en las universidades mexicanas: entre las presiones inmediatas, el bien público y la sumisión al capital. In C. Guillermo, P. Fernando, \& F. S. Andrea (Eds.), Transformaciones recientes de las Universidades Latinoamericanas. Agendas y actores en la producción del conocimiento (Edición electrónica) (pp. 135-166). Argentina: Benemérita Universidad Autónoma de Puebla/ Universidad Nacional del Centro de la Provincia de Buenos Aires/ Universidad Autónoma de Zacatecas.

Acosta Silva, A. (2010). Príncipes, burócratas y gerentes: El gobierno de las Universidades públicas en México (2a. ed.). México: ANUIES, dirección de medios editoriales/Unión de Universidades de América Latina (UDUAL).

Almond, G., \& Verba, S. (1963/1970). La cultura civica. Estudios sobre la particiapción política democrática en cinco naciones. Madrid, España: Euramerica/Fundación Fomento de estudios sociales y de sociología aplicada.

Galaz Fontes, J. F. (2014). La cultura institucional en las universidades públicas mexicanas. Retrieved from http://red-academica.net/observatorio-academico/2014/06/10/la-cultura-institucional-en-lasuniversidades-publicas-mexicanas/

Garduño Madrigal, F. (1997, Octubre). La docencia como profesión: sus nuevos retos (estudio monográfico) (Vol. Universitas. Cuadernos del centro de estudios de la universidad. No. 18). Estado de México: Universidad Autónoma del Estado de México.

Gil Antón, M. (1994). Los rasgos de la diversidad. Un estudio sobre los académicos mexicanos (Primera ed.). México: Universidad Autónoma Metropolitana Azcapotzalco.

González Casanova, P. (2001). La universidad necesaria en el siglo XXI (1 ${ }^{\mathrm{a}}$ ed.). México: Ediciones Era. 
Ibarra Colado, E. (2001). La Universidad en México hoy: Gubernamentalidad y modernización. México: UNAM

Linton, R. (1945/1978). Cultura y personalidad. México: FCE.

Lora Cam, J. V., \& Recendez Guerrero, M. C. (2009). De la contrareforma universitaria neoliberal a la resistencia en América Latina Buenos Aires, Argentina: elaleph.com.

Martínez Espinoza, Y. (2006). México ante la imperante necesidad de fortalecer la educación pública superior como vía estratégica para su desarrollo En busca de México. Una visión de los que crecieron en la crisis (pp. 105-119). México: Ediciones y gráficos Eón.

Mungaray, A., Ocegueda, J. M., \& Ocegueda, M. T. (2006). Disminuyendo las brechas entre las universidades públicas estatales en México. Una evaluación del financiamiento público entre 1988 y 2003. Gestión y política pública, XV, Num. 1, 145-168. Retrieved from http://www.gestionypoliticapublica.cide.edu/

Pallán Figueroa, C. (2014). La política y lo político en la universidad La Universidad Pública en México. Análisis, Reflexiones y Perspectivas (pp. 115-126). México: UNAM/Maporrua.

Pérez-Jiménez, C. (2003). Formación de docentes para la construcción de saberes sociales. Revista Iberoamericana de Educación. $N^{o} 33$, pp 37-54. Retrieved from http://www.rieoei.org/rie33a02.htm

Porter Galetar, L. (1999/2000). El alma del académico. Toronto/México. Retrieved from http://academia.uat.edu.mx/porter/Publicaciones/alma.htm

Rodríguez Jaume, M. J. (2000). Modelos sociodemográficos: Atlas social de la ciudad de Alicante. (Doctorado), Universidad de Alicante, España.

Rubio Oca, J., (Coord.). (2006). La política educativa y la educación superior en México. 1995-2006: Un balance. México: Fondo de Cultura Económica/Secretaría de Educación Pública.

Sánchez Puentes, R. (1998). La crisis de la investigación en la Educación Superior. Retrieved from http://www.anuies.mx/servicios/p_anuies/publicaciones/revsup/res065/txt8.htm

Sanz Blas, S., Ruiz Mafé, C., \& Pérez Pérez, I. (2014). El profesor universitario y su función docente. Espacio I+D, Innovación más Desarrollo, III, No. 5, 97-112.

Sodaro, M. J. (2004/2006). La cultura política. In J. M. Cejudo (Ed.), Política y ciencia política: Una introducción (2a. esp. ed., pp. 209-226). Madrid: McGraw-Hill/interamericana de españa S.A.V.

Young, K., Germani, G., Flügel, J. C., \& Argyle, M. (1967). Psicología de las Actitudes. Madrid: Paidos.

Yurén, T., \& Izquierdo, I. (2008, 1 de noviembre 2011). Ética y quehacer científico. De la estrategia identitaria a la estrategia política. Perfiles Educativos. Retrieved from http://redalyc.uaemex.mx/pdf/132/13208803.pdf 